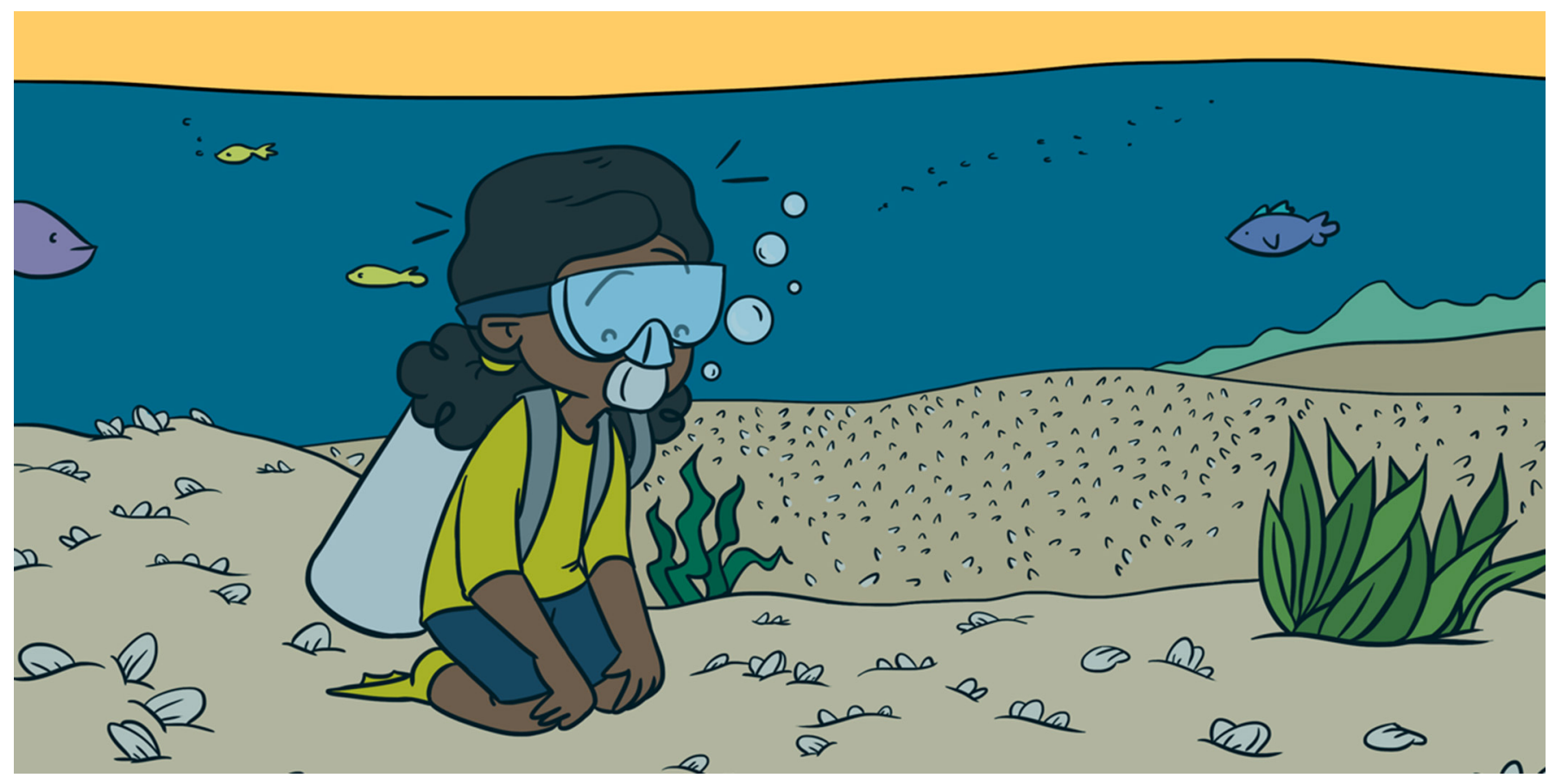

\title{
IF YOU GIVE A CLAM AN ESTUARY: THE STORY OF POTAMOCORBULA
}

\section{Kelly H. Shrader, Emily L. Zierdt Smith, Francis Parchaso * and Janet K. Thompson}

\section{U.S. Geological Survey, Benthic Laboratory, Menlo Park, CA, United States}

\section{YOUNG REVIEWERS:}

ISABEL

AGE: 11

MARGARIDA

AGE: 13

MAYA

AGE: 10
When you look at San Francisco Bay, what animals do you see? You may see lots of fish, birds, harbor seals, and sea lions. What you do not see is a little clam (Potamocorbula amurensis) that changed the Bay. Many years ago, ships accidentally brought this clam into the Bay from Asia. Soon, they spread out all over in large numbers. Clams pump water through their gills and eat small particles of food that are in the water, like phytoplankton (microscopic aquatic plants) and other microscopic critters. Potamocorbula can pump water faster than other clams, and they can eat more than their share of phytoplankton. Sometimes, Potamocorbula eats phytoplankton faster than phytoplankton can grow! What problems does that cause for other animals that also eat phytoplankton? Does Potamocorbula's invasion only have negative impacts? In this article, we dive to the bottom of the Bay to find some answers. 


\section{ESTUARY}

Habitats where fresh water from rivers mixes with salty water from the ocean. Estuaries contain both fresh and salty water places where many plants and animals can live and grow.

\section{INVASIVE SPECIES}

Species introduced to an area that survive, reproduce, and spread, causing problems in the new area.

\section{BALLAST WATER}

Water carried by boats for balance that can be emptied and refilled while moving or stationary. Animals can be moved and released in new habitats when in the expelled water.

\section{SALINITY}

The amount of salt in a body of water.

\section{Figure 1}

Initial spread and distribution of Potamo in San Francisco Bay, from 1986 to 1987. When it was introduced in 1986, there were only a few Potamo found in the area. Just 6 months later, there were clams all over the northern end of San Francisco Bay! One year after they were first introduced, there were thousands of Potamo in the Bay, and they are still there today.

\section{WHO IS POTAMO?}

San Francisco Bay is an estuary that is home to many different species. If you look around the Bay, you may find fish, birds, harbor seals, and even sea lions. What you cannot see are the worms, crabs, and clams that live on the bottom of the Bay. Potamocorbula amurensis, as scientists call it, is a species of clam that can be found across the world. We nicknamed this clam Potamo. As an invasive species, Potamo came from somewhere else and changed their new home. In 1986, ships accidentally brought Potamo into the San Francisco Bay from Asia in their ballast water [1]. Soon after they arrived, Potamo liked their new home so much that they spread rapidly. Eventually, there were over 10,000 clams per square meter, which is the same as having 2,800 clams spread out on top of your school desk [1] (Figure 1)! But how could Potamo spread so much, and how did their invasion change San Francisco Bay?

\section{POTAMO'S SPREAD AND SUCCESS IN SAN FRANCISCO BAY}

There are four factors that allowed Potamo to spread out and be successful in the Bay. First, Potamo tolerate many different levels of salt in the water, known as salinity, and that allows them to survive when salinity changes in the bay $[1,2]$. Second, Potamo survive in

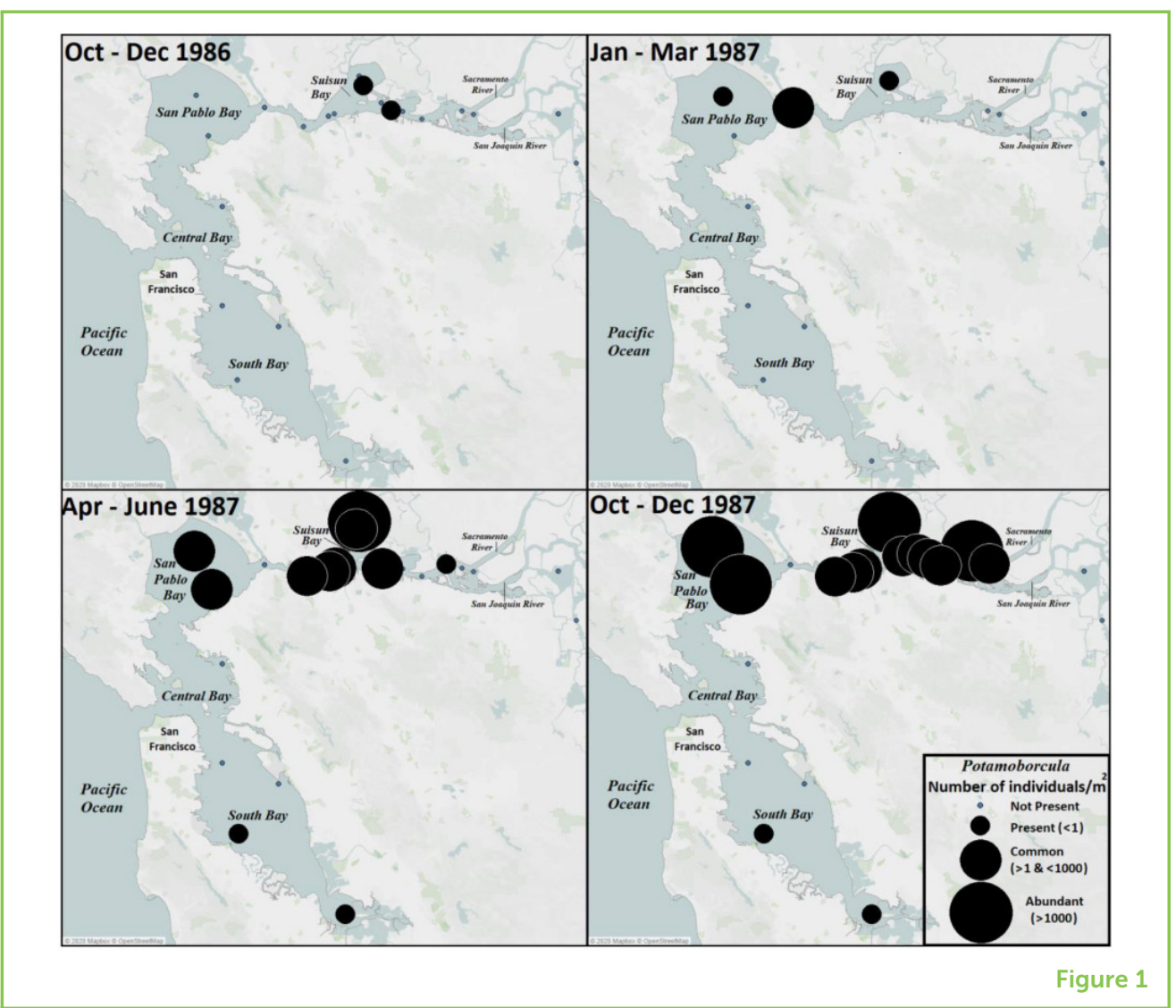


Figure 2

A clam brings water in through its siphon (white arrow) and filters the water through its gills to remove food particles such as phytoplankton that are suspended in the water The clam then expels the water back out through the other part of its siphon (black arrow).

\section{SEDIMENT}

The material that settles to the bottom of a body of water, like mud, sand, and silt.

\section{FILTER-FEEDING}

A method of eating that separates suspended food particles from water by passing the water through a filtering structure, like gills. Some animals that filter-feed are clams, whales, and fish.

\section{PHYTOPLANKTON}

Tiny, drifting plants that live in the water and get energy from the sun and nutrients from the water. Phytoplankton are eaten by zooplankton, clams, fish, and whales.

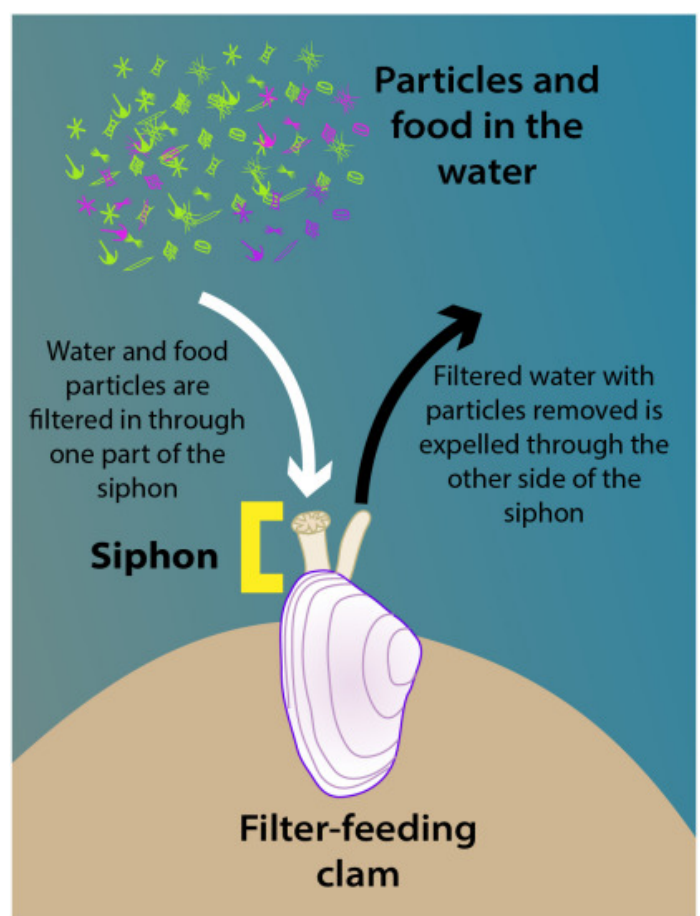

Figure 2

different types of sediment, or material that make up the bottom of the Bay, such as mud and sand. This makes Potamo even better at living in many parts of the bay because they can get comfortable no matter what sediment they live in [1, 2]. Third, the clams live in both deep and shallow parts of the Bay [1, 2]. Fourth, Potamo survive in the cold winter and the hot summer water temperatures [1]. Their ability to survive in all these different conditions allowed Potamo to spread out all over San Francisco Bay.

Like other clams, Potamo eat using a process called filter-feeding. Unlike humans, clams do not have heads, so they do not eat like we do. Instead, they have gills like fish and tubes called siphons that they use to eat and breathe. Clams can extend their siphons out of their shells like a straw to suck water. The gills act as a screen that traps the food particles that are in the water, allowing clams to filter and expel the water and keep the food. From the gills, the food particles move toward the mouth where they are eaten and digested [2] (Figure 2).

Potamo filter water very quickly, which means they can eat a lot of food in a short period of time [3]. For example, 300 clams in a square meter, or 30 clams in a square foot, can filter 3,785 liters of water in 1 day. That is enough water to fill over 23 bathtubs [4]! Potamo are also not picky eaters and can eat different organisms, such as phytoplankton and bacteria [1]. This means that they always have something to eat. 
Figure 3

(A) Before Potamo arrived in San Francisco Bay, phytoplankton supported large fish populations. The black arrows show what eats what in the food web.

(B) After the invasion of Potamo, less

phytoplankton was available for other species to eat, which changed the food web. The red arrow indicates that Potamo eat more phytoplankton than the other species in the diagram (The images used in the figure are courtesy of Tracey Saxby, Dieter Tracey, Kim Kraeer, Lucy Van Essen-Fishman, and Jane Thomas from the Integration and

Application Network, University of Maryland Center for

Environmental Science (ian.umces.edu/symbols/), and Kamil Sulima from svg-clipart.com for the scaup).

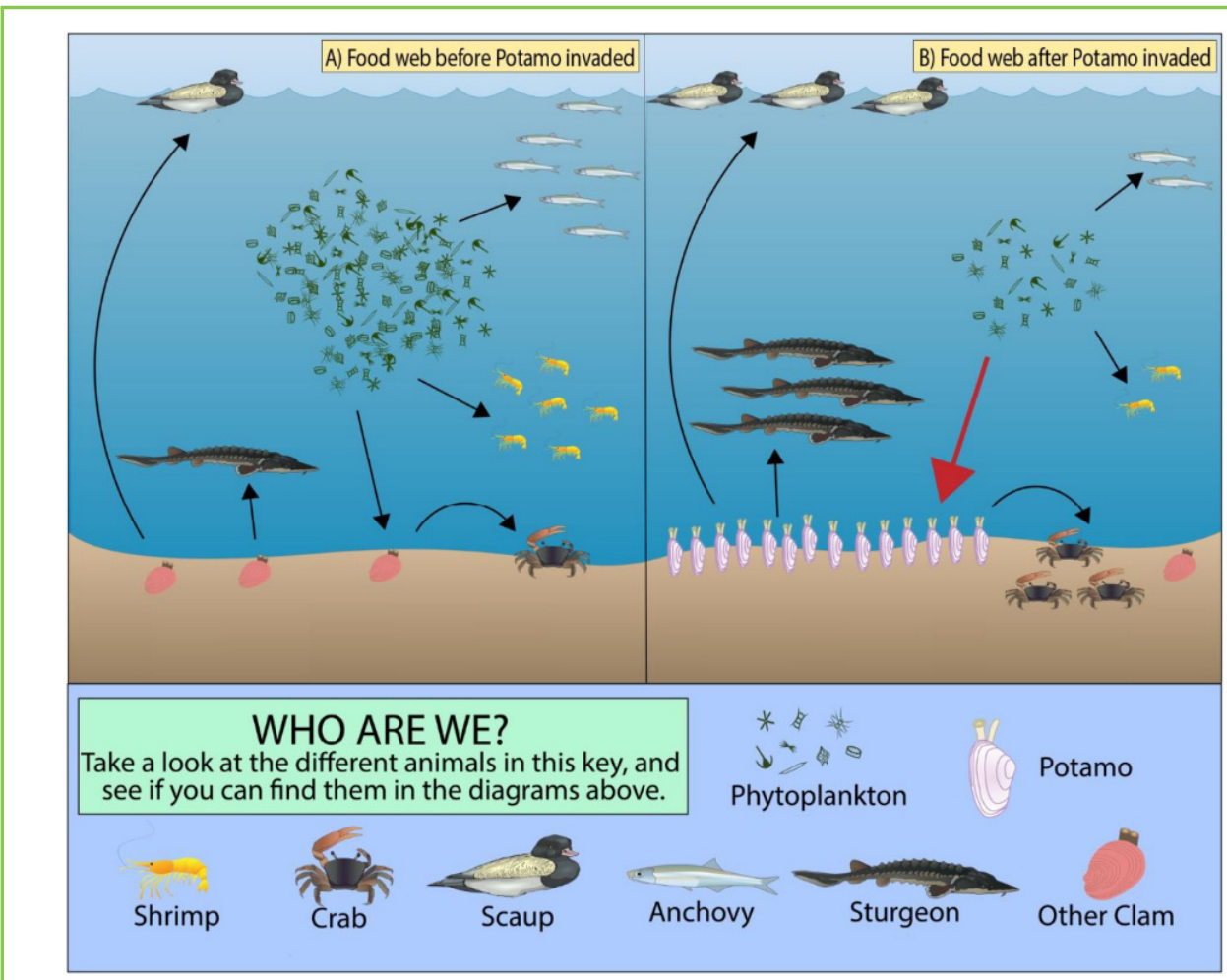

Figure 3

Potamo occupy the same territory as other animals, and they have several different ways to compete with unwanted neighbors. They burrow near the sediment surface, sometimes leaving one-half to two-thirds of their shells above the sediment. By sticking out of the sediment, Potamo do not leave much surface space for other animals to settle. The clams can also live very close together, which makes it hard for other animals to find enough space to settle next to them. Potamo's large numbers, shallow burrowing, and efficient filter-feeding limit space and food for potential neighbors. When combined with Potamo's ability to tolerate many different environmental conditions, they can outcompete many other species [1].

\section{PHYTOPLANKTON AND THE VERY HUNGRY CLAM}

One of things that Potamo like to eat is phytoplankton. Phytoplankton are an important part of the food web, and many other creatures rely on them. Before Potamo invaded the Bay, the amount of phytoplankton changed seasonally; their numbers were low during winter and spring and "bloomed" during summer and fall. After Potamo arrived and spread out, phytoplankton numbers remained low during summer and fall when they normally peaked [3]. Since Potamo's arrival, phytoplankton has consistently decreased. Potamo can eat phytoplankton faster than phytoplankton can grow, which can limit phytoplankton from blooming [4] (Figure 3). 
Luckily, Potamo cannot wipe out all the phytoplankton, due to the depth and flow of the water. In shallow water, Potamo pump all the water above them and quickly eat the available phytoplankton. However, in deep water, Potamo can only filter the water near the bottom, so the phytoplankton near the surface are safe. The flow of water can also move phytoplankton away from the clams before Potamo have time to filter the water, so the phytoplankton can escape being eaten [3].

Freshwater from rivers and rain mix with salty ocean water to change the estuary's salinity, and animals respond to these changes. Phytoplankton move with the water, so they are exposed to changes in salinity as tides push the water back and forth between the ocean and Bay. Clam populations also move with salinity, but in a different way over a much longer time. Baby clams float in the water and settle in new places as they are pushed around by the tides, much like seeds floating in a gentle breeze. However, like trees that put down roots, individual clams cannot leave once they settle on the bottom. Therefore, Potamo cannot chase phytoplankton, but must wait for phytoplankton to come to them [4].

Phytoplankton are at the base of the food web, which means they are a food source for animals like clams and fish. The clams and fish are then eaten by other animals, like larger fish and crabs, which can then be eaten by bigger animals, like ducks, sharks, and sea lions. When there are not enough phytoplankton, the entire food web is affected. Zooplankton are small organisms that live in the water that can eat phytoplankton. Since Potamo moved in and started eating so much phytoplankton, the number of zooplankton has decreased, and zooplankton predators (like shrimp and anchovies) have less to eat and have also decreased since Potamo have invaded the Bay [4] (Figure 3).

\section{IS POTAMO BAD NEWS FOR EVERYONE?}

Potamo's invasion is not only negative! The large numbers of Potamo have made more food available for bottom feeders such as diving ducks, sturgeon, and crabs [1,4]. One of the species that benefits from Potamo is the lesser scaup, a bottom-feeding migratory bird that spends winters in the Bay [5]. Before Potamo, the lesser scaup fed on a native clam, called Macoma balthica (nicknamed Macoma).

Let us take look at the details of clams as prey. The amount of energy scaups get from clams depends on many factors: how nutritious the clam is, how easily it is digested, how deep the clam is buried, and how many clams a scaup eats during one dive. The best food source gives scaups the most energy-more energy than they use to catch, digest, and crush the clams [5]. Potamo have higher nitrogen and fat content, and three times the energy available than Macoma. Potamo's shells are 
thicker and harder to crush than Macoma's, yet Potamo are the better food source. Scaups spend more energy digesting Potamo's shells, but they get more energy back from eating Potamo than Macoma [5].

Potamo are more available than Macoma, and scaups can capture more clams during a single dive by eating Potamo. Diving takes a lot of energy for a bird-they must hold their breath and push against the water pressure to get to the bottom. Therefore, they want to capture as many clams as possible per dive. Scaups eat clams buried $<5$ centimeters (about 2 inches) deep. Most Potamo live within this range, while only half of Macoma live at these same shallow depths [5]. So, overall, Potamo are a better food source for the lesser scaup than Macoma are.

\section{POTAMO: MAYBE GOOD, MAYBE BAD, AND DEFINITELY HERE TO STAY}

While San Francisco Bay is not Potamo's original home, they show no signs of leaving. Humans do not eat these clams, so we must depend on their predators to control the clam populations. As we have explained, Potamo have both helped and harmed its new home. Food webs can be messy, and relationships between species can become complicated as new species are introduced, as with Potamo. While the future of San Francisco Bay species and Potamo's dominant status in the Bay remain unknown, one thing is certain: nature is always changing and evolving.

\section{REFERENCES}

1. Carlton, J. T., Thompson, J. K., Schemel, L. E., and Nichols, F. H. 1990. Remarkable invasion of San Francisco Bay, (California, USA) by the Asian clam Potamocorbula amurensis. I. Introduction and dispersal. Mar. Ecol. Prog Ser. 66:81-94. doi: 10.3354/meps066081

2. Dame R. F. 2011. Ecology of Marine Bivalves: An Ecosystem Approach. 2nd Edn. Boca Raton, FL: CRC Press.

3. Alpine, A. E., and Cloern, J. E. 1992. Trophic interactions and direct physical effects control phytoplankton biomass and production in an estuary. Limnol Oceanogr. 37:946-55. doi: 10.4319/lo.1992.37.5.0946

4. Kimmerer, W. J., and Thompson, J. K. 2014. Phytoplankton growth balanced by clam and zooplankton grazing and net transport into the low-salinity zone of the San Francisco estuary. Estuaries Coasts 37:1202-18. doi: 10.1007/s12237-013-9753-6

5. Richman, S. E., and Lovvorn, J. R. 2004. Relative foraging value to lesser scaup ducks of native and exotic clams from San Francisco Bay. Ecol. Appl. 14:1217-31. doi: 10.1890/03-5032

SUBMITTED: 26 August 2020; ACCEPTED: 16 August 2021; PUBLISHED ONLINE: 09 September 2021. 
EDITED BY: Pedro Morais, University of Algarve, Portugal

CITATION: Shrader KH, Zierdt Smith EL, Parchaso F and Thompson JK (2021) If You Give a Clam an Estuary: The Story of Potamocorbula. Front. Young Minds 9:599289. doi: 10.3389/frym.2021.599289

CONFLICT OF INTEREST: The authors declare that the research was conducted in the absence of any commercial or financial relationships that could be construed as a potential conflict of interest.

COPYRIGHT @ 2021 Shrader, Zierdt Smith, Parchaso and Thompson. This is an open-access article distributed under the terms of the Creative Commons Attribution License (CC BY). The use, distribution or reproduction in other forums is permitted, provided the original author(s) and the copyright owner(s) are credited and that the original publication in this journal is cited, in accordance with accepted academic practice. No use, distribution or reproduction is permitted which does not comply with these terms.

\section{YOUNG REVIEWERS}

\section{ISABEL, AGE: 11}

Hello, I am Isabel. I am 11 years old and I really like writing stories. I also like reading. I am really interested in diplomacy.

\section{MARGARIDA, AGE: 13}

My name is Margarida, I am 13 years old and I like reading, climbing, and writing. I love science, especially anything about black holes and I have absolutely no idea what I want to do when I grow up. I also really like biology.

\section{MAYA, AGE: 10}

Maya loves to draw and learn about animals. Her favorite subject is reading and she just read a book about cats! She likes to look for insects outside. This summer she went swimming in the Lake Michigan in Chicago.

\section{AUTHORS}

\section{KELLY H. SHRADER}

I am a biologist with the U.S. Geological Survey (USGS), Water Mission Area. My interest in ecology started when I was in elementary school, watching the animals in my own backyard interact with one another and their environment. My desire to pursue research began at U.C. Santa Cruz, where I received a degree in ecology and evolutionary biology. I am interested in spatial ecology, or where animals are found in the environment and why. My work in the Benthic Laboratory investigates where two species of invasive clams live in San Francisco Bay and what impact they have on other animals. 

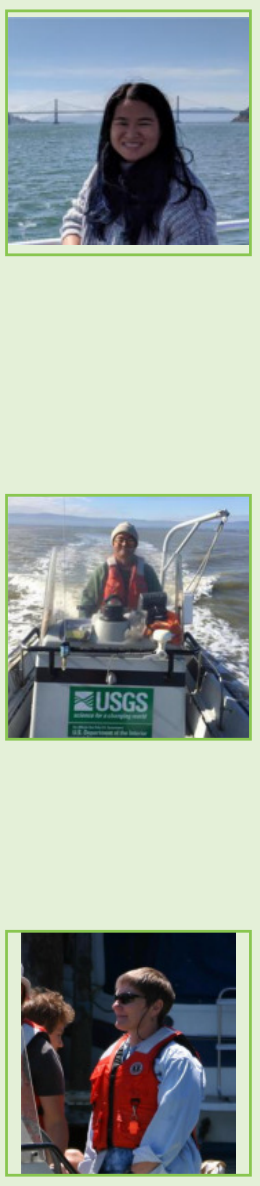

\section{EMILY L. ZIERDT SMITH}

I am a biologist with the U.S. Geological Survey Benthic Laboratory. Ever since I was little, I have been interested in being outside, always running from tree to tree, to rocks, and to nearby streams. I took my passion for being outdoors to U.C. Santa Cruz, where I received a degree in environmental studies and a degree in ecology and evolutionary biology. I am interested in the restoration and conservation of different ecosystems. Our laboratory studies how the community of animals that live on the bottom of the San Francisco Bay changes and the long-term impacts of those changes.

\section{FRANCIS PARCHASO}

I am a biologist at the U.S. Geological Survey. I have a master's degree in marine biology. I work with a team of scientists that studies San Francisco Bay. I study benthic animals, that is, the animals that live in the bottom of San Francisco Bay. My research includes clam feeding behavior, reproduction, and physiology, as well as the effects of clams on the food web and ecosystem. Our work involves a lot of time on a boat collecting samples and time in the laboratory identifying and counting all the animals that we find in the samples. *parchaso@usgs.gov

\section{JANET K. THOMPSON}

I have been a biologist at the U.S. Geological Survey for $40+$ years. I have a master's degree in marine biology and a Ph.D. in civil engineering. My work is focused on understanding how animals that live on the bottom affect the structure of the aquatic ecosystem and how changes in which species live on the bottom can result in long-term changes to the food web. Having spent most of those 40+ years going into the field, I now spend much of my time analyzing the data and writing. 